\title{
Marine debris trends: 30 years of change on Ventura County and Channel Island beaches
}

\author{
Michaela Miller ${ }^{1}{ }^{*}$, Clare Steele ${ }^{1}$, Dorothy Horn ${ }^{2}$, and Cause Hanna ${ }^{3}$ \\ ${ }^{1}$ California State University Channel Islands, Camarillo, CA \\ ${ }^{2}$ Portland State University, Portland, OR \\ ${ }^{3}$ Santa Rosa Island Research Station, California State University Channel Islands, Camarillo, CA
}

\begin{abstract}
The persistence of plastics in marine ecosystems and the physical hazards marine debris pose to wildlife have become issues of global concern. The Santa Barbara Channel is home to a number of important marine and coastal ecosystems, including the 5 islands of Channel Islands National Park, and has a variety of factors that influence marine debris accumulation. We examined the spatial variation of marine debris density and composition across the Santa Barbara Channel by quantifying marine debris on beaches of Santa Rosa and Santa Cruz Islands and the Ventura County mainland. Debris from surveyed beaches was cataloged, weighed, and measured to compare differences in island and mainland marine debris abundance, density, and composition. Derelict fishing gear accounted for a higher proportion of marine debris on island beaches compared to mainland beaches, and marine debris items on island beaches were significantly heavier compared to debris items on mainland beaches. The majority of debris on mainland beaches comprised smaller plastic fragments and single-use plastic items, and debris accumulation rates varied by season and location. Microplastics (plastic fibers and particles $<5 \mathrm{~mm}$ ) were found in the sand of all island and mainland beaches; however, density of microplastics did not appear to correlate with density of visually observable debris items $(>25 \mathrm{~mm})$ that were collected during marine debris cleanups. We compared our data from 2015 and 2016 with historical surveys performed from 1989 to 1994 to examine the temporal variation of marine debris on Santa Rosa Island. We found that there has been a significant increase in the amount of derelict fishing gear found on Santa Rosa Island over the past 27 years, which mirrors expansion of the California spiny lobster (Panulirus interruptus) fishery. This study highlights the importance of marine debris monitoring, as local changes in policy, fisheries, and consumer culture are reflected in accumulations of marine debris found on the California mainland and the uninhabited Channel Islands. Monitoring marine debris can provide insight into anthropogenic impacts and is a useful mechanism in monitoring the health of coastal and marine ecosystems.
\end{abstract}

Resumen.-La presencia de plástico en los ecosistemas marinos, así como la amenaza que los desechos marinos significan para la vida silvestre se han convertido rápidamente en un problema global. El canal de Santa Barbara es hogar de un gran número de ecosistemas marinos y costeros, los cuales incluyen a las cinco islas que forman parte del parque nacional "Channel Islands," el cual consta de una gran variedad de factores que influyen en la acumulación de dichos desechos. Cuantificamos los desechos marinos de las playas en las islas Santa Rosa y Santa Cruz, así como en la costa del condado de Ventura para examinar la variación espacial en la densidad y composición de desechos marinos a lo largo del canal de Santa Barbara. Los desechos obtenidos en dichas playas fueron catalogados, pesados y medidos con el fin de comparar la diferencia en abundancia, densidad y composición de los desechos entre las playas de las islas y del condado. Notamos que los desechos en las playas de las islas tienden a ser más pesados y a contar con una mayor cantidad de equipo de pesca abandonado que las playas del condado, las cuales contaban con plásticos más pequeños y desechables, y cuya acumulación varía mucho dependiendo de la estación y la localización de la playa. Encontramos micro plásticos (fibras de plástico y partículas $<5 \mathrm{~mm}$ ) en la arena de todas las playas que fueron estudiadas, sin embargo, la densidad de plástico no parece estar correlacionada con la densidad de objetos más grandes $(>25 \mathrm{~mm}$ ) que fueron recolectados en días de recolección de desechos marinos en las playas de nuestro estudio. También comparamos nuestros resultados con encuestas científicas realizadas entre 1989 y 1994 para examinar la variación temporal de desechos en la isla de Santa Rosa y encontramos que ha habido un incremento significativo en la cantidad de equipo de pesca abandonado que ha sido encontrado en los últimos 27 años en ésta isla, lo cual refleja el rápido crecimiento de la industria pesquera enfocada en las langostas de California. Éste estudio hace hincapié en la importancia del monitoreo de desechos marinos, ya que los cambios en la industria pesquera, implementación o cambios en leyes y la cultura del consumidor son reflejadas en la acumulación de dichos desechos en la costa de California y hasta en las islas "Channel Islands," que son inhabitadas, también, dicho monitoreo puede brindar información en impactos antropogénicos, y ayudar a supervisar la salud de los ecosistemas tanto costeros como marinos.

*Corresponding author: michaela.miller@csuci.edu 
Anthropogenic marine debris increasingly threatens marine wildlife and the health of the world's oceans (Barnes et al. 2009) and is considered an issue of global concern and a manifestation of human impact on the marine environment (Ribic et al. 2010). Even remote and uninhabited islands accumulate oceanborne debris (Lavers and Bond 2017). It is widely documented that marine debris causes significant harm to human health, wildlife, ecological function, biodiversity, beach quality, navigational safety, and the economic success of fisheries (Chen and Liu 2013). Mitigation and source reduction efforts may be limited by our understanding of accumulation patterns. Marine debris monitoring programs can provide insight and quantitative information on how policy, consumer culture, and global events contribute to the anthropogenic impact on marine and coastal areas (Ribic et al. 2010).

Plastics are by far the most common, persistent, and conspicuous pollutant in coastal and marine environments around the world (Derraik 2002, Moore 2008). Global plastics production is on the scale of hundreds of millions of tonnes annually (PlasticsEurope Facts Sheet 2015, www.plasticseurope.org), and plastics compose the majority of debris items polluting coastal and marine environments (Engler 2012, Ivar do Sul and Costa 2014). The longevity and durability of plastics that make them so valuable to society also cause ecological harm; it is estimated that the longevity of plastics can be hundreds to thousands of years in marine environments (Barnes et al. 2009).

Anthropogenic litter becomes marine debris when it enters the marine environment via land-based or ocean-based sources (Derraik 2002, Andrady 2011). Understanding the primary sources of marine debris for a particular region can assist policymakers and managers with source reduction efforts (Ribic et al. 2012). Up to $80 \%$ of marine debris (Chen and Liu 2013) is land based and is introduced into the marine environment via improper disposal, accidental loss of debris into natural waterways, sewage and drainage systems, and by storm events or natural disasters (Watters et al. 2010, Rech et al. 2014). The direct dumping of anthropogenic litter (e.g., cigarette butts) into coastal zones and marine areas also contributes to land-based sources (Bravo et al. 2009). In the United States, 53\% of the nation's population lives in coastal zones
(Crossett et al. 2004). The influx of people living along the coast leads to increased marine debris pollution from land-based sources (Moore et al. 2011).

Ocean-based litter, generated from vessels or fisheries-related activities, contributes $20 \%$ of marine debris (Moore et al. 2009, Chen and Liu 2013). The majority of ocean-based marine debris is composed of abandoned, lost, or otherwise discarded fishing gear (Macfadyen et al. 2009, McElwee et al. 2012) and waste from commercial ships (Chen and Liu 2013). Possibly the most ecologically harmful component of ocean-based marine debris is derelict fishing gear, which is gear no longer tended by a fisherman, such as traps, lines, and buoys (Anderson and Alford 2014). Although debris generated from fishing vessels is a relatively small component of marine debris compared to land-based sources, it can have particularly severe impacts on marine wildlife because of the higher risk of entanglement or because of "ghost fishing" associated with derelict fishing gear (Moore et al. 2009, Morishige and McElwee 2012, Gilman 2015). Marine megafauna (Johnson et al. 2006), including the critically endangered Gulf of California harbor porpoise or "vaquita" (Phocoena sinus), are endangered by entanglement in active and derelict fishing gear, despite the fauna's legally protected status (Díaz-Uribe et al. 2012).

Marine organisms are imperiled by the ingestion of plastic and other debris via impaction, false satiation, and toxicity (Derraik 2002). Plastic is manufactured with additives, such as plasticizers, that can leach out of the plastic into the environment and into organisms that ingest plastic, making plastic debris a danger to all forms of aquatic life (Brander et al. 2011). Plastics can also adsorb ambient, persistent toxic chemicals from the water or sediment (Gouin et al. 2011). The bioaccumulation of toxins from ingested plastics has the potential to move even farther up the food chain and affect human health (Moore 2008, Engler 2012).

Ecologically, plastic pollution of all sizes is especially harmful to wildlife. The persistence of plastic and its tendency to fragment into smaller and smaller pieces has caused widespread marine debris pollution on a microscopic level (Browne et al. 2011). Plastic debris in the environment fragments due to solar radiation and weathering and forms 


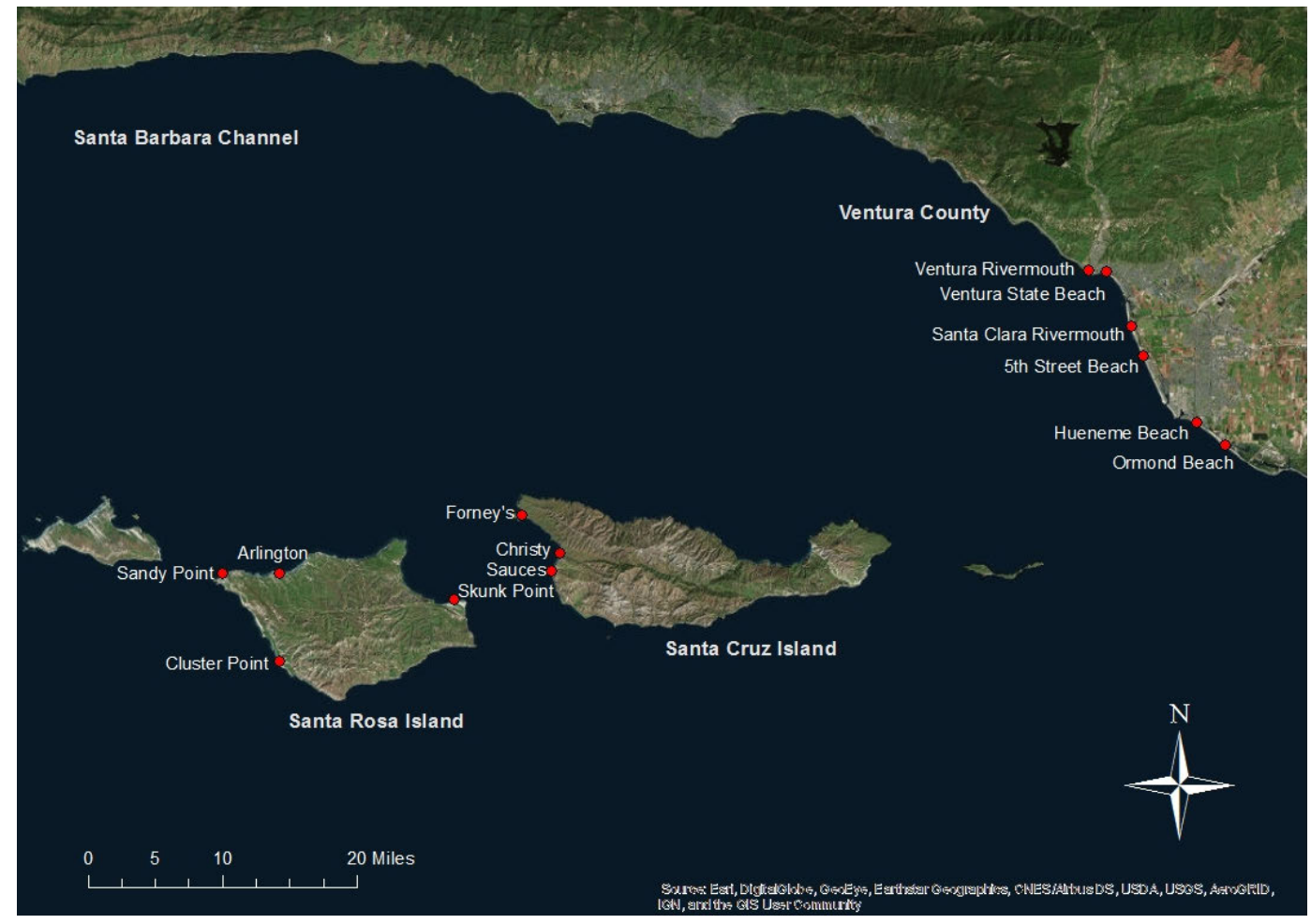

Fig. 1. Locations of marine debris accumulation surveys and removal sites in the Southern California Bight.

smaller and smaller pieces of plastic (Andrady 2011, Engler 2012), often resulting in microplastics, which are classified as plastics $<5 \mathrm{~mm}$ in size (Andrady 2011, Lippiatt et al. 2013). Other manufactured microplastics are microbeads used in cleaning and personal care products (Gregory 1996, Fendall and Sewell 2009) and synthetic fibers shed during laundry. These beads and fibers make their way past standard wastewater treatment plants (Browne et al. 2011).

We quantified the density and composition of marine debris that accumulated on the shoreline of 2 islands in California's Santa Barbara Channel (Santa Rosa and Santa Cruz Islands) and compared the density and types of debris with sites on the mainland shoreline. Ventura County mainland beaches are relatively close to the sandy beaches of the Channel Islands but differ in usage, visitor count, and proximity to urban areas. This comparison allowed us to identify differences in island and mainland debris composition and density. At sites on the Channel Islands and the mainland, we examined the distribution of microplastics in beach sediments and compared the distribution and amounts of macroand microplastics.

Comparison of our data with data from a marine debris survey funded by the National Fisheries Service within Channel Islands National Park from 1989 to 1994 allowed us to examine the temporal variation in marine debris accumulation and composition (Cole 1998) and enabled us to assess how marine debris composition and abundance has changed on Channel Island beaches over the last 27 years.

\section{METHODS}

\section{Study Location}

The Southern California Bight comprises the coastal ocean off the west coast of the United States between Point Conception in Santa Barbara County and the Mexican border in San Diego County (Noble et al. 2012; Fig. 1). The geographic area is unique because of its productive marine environment caused by the mixing of the cool, nutrient-rich waters brought down from the West Coast of North America by 
the California Current, and the warm, highsalinity California Undercurrent that originates in the tropical eastern Pacific Ocean (Taylor et al. 2015). The Southern California Bight is also home to the Santa Barbara Channel, which includes over $6000 \mathrm{~km}^{2}$ of coastal waters between the coast of California and the Northern Channel Islands in the Southern California Bight (Warrick et al. 2004a).

The coastlines of the Santa Barbara Channel encompass a wide array of diverse marine and coastal environments, as well as dense urban populations (Warrick et al. 2004a). The coastal counties of Santa Barbara, Ventura, and Los Angeles have populations ranging from 400,000 to $10,000,000$ people (United States Census Bureau 2018). Approximately $80 \%$ of the mainland coast in the Santa Barbara Channel is composed of sandy beaches (Dugan et al. 2000), which are heavily used by humans. A stark contrast to the mainland is the coasts of the Channel Islands: 175 miles of undeveloped coastlines a mere 60 miles away (Dugan et al. 1998). The Channel Islands National Park consists of 5 of the 8 Channel Islands: San Miguel, Santa Rosa, Santa Cruz, Anacapa, and Santa Barbara. The Channel Islands National Marine Sanctuary overlaps the subtidal areas of the park and extends 6 miles out into the ocean from the park's islands. The isolated sandy beaches within Channel Islands National Park are important habitat for breeding populations of 4 species of pinnipeds: California sea lions (Zalophus californianus), northern fur seals (Callorhinus ursinus), harbor seals (Phoca vitulina), and northern elephant seals (Mirounga angustirostris) (Bartholomew and Boolootian 1960). These remote sandy beach ecosystems are also nesting sites for the endangered western Snowy Plover (Charadrius nivosus nivosus) (Dugan et al. 2000) and provide food resources for the recently delisted island fox, (Urocyon littoralis) (Coonan et al. 2005).

The Santa Barbara Channel and the Channel Islands are important habitat for commercial and sport fisheries such as kelp bass (Paralabrax clathratus) and California sheephead (Semicossyphus pulcher) (Caselle et al. 2015), California spiny lobster (Panulirus interruptus) (Kay et al. 2012), and red sea urchin (Mesocentrotus franciscanus) (Kato and Schroeter 1985) fisheries. These fisheries, which are important to the economies of
Ventura and Santa Barbara Counties (Chen and Lopez-Carr 2015), also deposit derelict fishing gear and other ocean-based marine debris throughout the Santa Barbara Channel and on the remote shorelines of the Channel Islands, where both recreational and commercial fishing debris have been documented (Schroeder and Love 2002). Marine debris is prevalent in both mainland coastal areas and remote shorelines on the Channel Islands and is a growing ecological issue in the Santa Barbara Channel (Ribic et al. 2012). A number of watersheds discharge into the Santa Barbara Channel, the largest of which are the Santa Clara and Ventura Rivers (Warrick et al. 2004a). These watersheds, along with the various harbors, storm drains, ships, vessels, beachgoers, and high urban populations, are major contributors to marine debris entering coastal systems throughout the Santa Barbara Channel (Moore and Allen 2000, Moore et al. 2011).

\section{Debris Accumulation Surveys}

Marine debris accumulation surveys were performed on 4 Santa Rosa Island (SRI) beaches, 3 Santa Cruz Island (SCI) beaches, and 6 mainland beaches in Ventura County throughout the cities of Ventura, Oxnard, and Port Hueneme. The 4 SRI beaches chosen for this study (Arlington Canyon, Cluster Point, Sandy Point, and Skunk Point) were part of the 1989-1994 marine debris survey funded by the National Marine Fisheries Service and performed by Channel Islands National Park personnel (Cole 1998). All 4 SRI beaches represent different exposures and positions on the island. SRI beaches were surveyed only twice during this study, in fall 2015 and spring 2016, due to winter storms impeding beach access. Cluster Point (SRI) was surveyed only once, during the fall, due to the presence of elephant seals (Mirounga angustirostris) throughout the spring. SCI beaches did not have an associated historical data set and were only surveyed once, in the winter of 2016. The SCI beaches-Christy Beach, Sauces, and Forney's-are on the Santa Cruz Island Preserve owned by The Nature Conservancy and are infrequently visited. SCI beaches were surveyed once in winter 2016. Mainland beaches were surveyed twice during this study: in fall 2015 and winter 2016. The surveyed mainland beaches-Ventura Rivermouth, Ventura State Beach, Santa Clara 
Rivermouth, 5th Street Beach, Hueneme Beach, and Ormond Beach-each represent unique areas within Ventura County, California, and different factors fostering marine debris accumulation. The Ventura Rivermouth and Ventura State Beach are adjacent to a popular bike path and promenade, as well as the Ventura County Fairgrounds. The pier and popular surf spot bring in many visitors. Ventura State Beach is subject to beach erosion due to the Matilija Dam and the consequent blocking of sediment (Willis et al. 2003). Because of episodic winter rainfall and dry summers (Warrick et al. 2004b), the Santa Clara Rivermouth has ephemeral discharge, which is another factor in marine debris accumulation. The Santa Clara Rivermouth is directly south of Ventura Harbor, the heavily trafficked Harbor Boulevard, and a water treatment facility. 5th Street beach is 3 miles south of the Santa Clara Rivermouth and also from the ephemeral discharge from the Santa Clara River. 5th Street beach is a popular choice for Oxnard beach visitors, is also backed by the busy Harbor Boulevard, and is near an NRG power plant (NRG Energy, Inc.; www.nrg.com). Hueneme Beach's associated pier and promenade make the beach a popular choice for visitors, surfers, and fishermen. Hueneme beach is also prone to beach erosion and is the focus of successive beach nourishment projects (Patsch and Griggs 2008). Ormond Beach is one of the few areas in southern California with an intact dunetransition zone marsh system. Ormond Beach is south of Hueneme Beach and directly adjacent to the Point Mugu Naval Air Station and another NRG power plant.

\section{Debris Collection and Categorization}

We used a modified NOAA Marine Debris Shoreline Survey Field Guide accumulation protocol (Lippiatt et al. 2013) at all sites to catalog and remove marine debris. Debris was collected from the swash zone (area where the waves wash up on the sand) to the back of the shoreline, as in the NOAA Marine Debris Shoreline Survey accumulation protocol and the Cole 1998 surveys; however, instead of surveying the entire length of the beach as per the protocol, we surveyed 3 random 100-m longshore band transects at each beach. The width of each transect coincided with the width of the beach, from the water line to the back of the beach, which was demarcated by a geomorphological change (e.g., dunes, vegetation, bluff, et cetera, depending on the beach), as in the NOAA Marine Debris Shoreline Survey accumulation protocol. Large accumulations of debris made removal of debris from the entire beach logistically infeasible, so 3 randomly placed 100-m band transects allowed adequate sampling of each beach to directly compare our data to the Cole 1998 data. All marine debris $(>2.5 \mathrm{~cm}$, as in Lippiatt et al. 2013) within each transect was collected separately for subsequent categorization and weighing. Geospatial data for each transect was recorded with a GPS (Garmin Oregon 650t), including waypoints at the start and end of each transect that were used to find the transect for the next consecutive survey and a polygon of the transect perimeter to measure total area surveyed.

We removed the collected marine debris and processed it off-site in the laboratory. The maximum length and width $(\mathrm{cm})$ of each debris item was measured, as well as the weight $(\mathrm{g})$ of each item. Items that were too small to be weighed individually, mostly hard plastic fragments and foam fragments, were weighed in groups of $20+$ and the average weight was recorded. Items that were too heavy to be removed from the beach (mostly on island sites where removed debris must be carried out) were measured at the beach, recorded, tagged, and left there. Heavy items left behind were tagged so the same item would not be recounted during the next survey. Items smaller than $2.5 \mathrm{~cm}$ in length were not counted, following the NOAA Marine Debris Shoreline Survey accumulation protocol. Each item's basic description was recorded and each item was assigned to a category (Cole 1998): derelict fishing gear, miscellaneous plastics, plastic packaging, personal effects, cloth/fabric, metal, glass, processed lumber, and rubber (Table 1). The categories were the same as those used in the 1989-1994 marine debris surveys, so our data are directly comparable to the historical database. For each marine debris item, the location, transect number, date, and season collected were recorded in the database.

\section{Microplastics Analysis}

At each beach, two 100-mL sand samples were collected from the top $5 \mathrm{~cm}$ of sand-one 
TABLE 1: Summary of categories used in marine debris classification.

\begin{tabular}{ll}
\hline Category name & Example items \\
\hline Lost fishing gear & $\begin{array}{c}\text { Lobster traps, fishing line, bait containers, net fragments, buoys, and any other } \\
\text { recreational or commercial fishing equipment }\end{array}$ \\
$\begin{array}{l}\text { Plastics } \\
\text { Miscellaneous }\end{array}$ & $\begin{array}{l}\text { Indistinguishable plastic items: foam fragments, hard fragments, film fragments } \\
\text { Packaging } \\
\text { Personal effects }\end{array}$ \\
$\begin{array}{l}\text { Food containers, water bottles, drink containers, straws, et cetera } \\
\text { Anything used by a person directly: cigarette butts, sunglasses, balloons, shoes, } \\
\text { hygiene products, toys, et cetera }\end{array}$ \\
$\begin{array}{l}\text { Nonplastics } \\
\text { Meth/fabric }\end{array}$ \\
$\begin{array}{l}\text { Towels, rags, fabric fragments, clothing, textiles, et cetera } \\
\text { Glass }\end{array}$ & Aluminum cans, aerosol cans, metal fragments, et cetera \\
Processed lumber & Cardboard cartons, paper and cardboard, paper bags, building material, corks \\
Rubber & Rubber gloves, flip-flops, tires, gloves, rubber fragments \\
\hline
\end{tabular}

from the swash zone and one from the strand line. Microplastics were density-separated from the sediment following methodology of Thompson et al. (2004). The filtered supernatant was examined for microplastics using stereomicroscopy, and items were counted and categorized by color and type. Density separation using saturated $\mathrm{NaCl}$ solutions produces conservative estimates of microplastics because higher-density polymers, including polyvinyl chloride and polyethylene terephthalate, do not float (Claessens et al. 2013); however, the density separation method allows comparison of microplastic density between sites.

\section{Data Analysis}

Waypoints from surveyed transects were uploaded into ArcGIS (Esri, Redlands, CA) to calculate the area surveyed. Since data from Cole's (1998) surveys were collected from the entire beach and not just a subset of the beach, we estimated the area of the beach by drawing a polygon of the beach length and width onto ArcGIS coverages of the beaches where surveys were conducted. We then used that area to calculate the historic density of marine debris in order to compare it to the current density.

To assess the change in debris composition, the proportion of each category was calculated by dividing the number of categorical items found by the number of total items found per beach. We then took the average proportions of the 1989-1994 data and compared them to the data collected during this survey. The average composition in 1989-1994 was compared to the average composition in 2015-2016 with a paired-sample $t$ test. Marine debris item density was calculated as the number of items per square meter (items $/ \mathrm{m}^{2}$ ). Marine debris mass density was calculated as the total mass of items per square meter. We used ANOVA to test for effects of year, season, and beach on historical (1989-1993) surveys of SRI beaches. Total item density (items $/ \mathrm{m}^{2}$ ) was log transformed $(\log [(100 *$ item density $)+1])$ to satisfy assumptions of normality.

\section{RESULTS}

\section{Islands and Mainland Marine Debris Accumulation Survey and Removal, Fall 2015 and Winter 2016}

In total, 8209 debris items were removed from Santa Rosa Island, Santa Cruz Island, and the mainland sites, weighing a total of $422.07 \mathrm{~kg}$. The composition of island and mainland debris items was significantly different (Fig. 2). Fishing gear composed a significantly greater percentage of debris items found on the island beaches than on mainland beaches $\left(t_{11}=3.03, P<0.01\right)$. There were no significant differences between other categories of debris items or the overall item density (items $/ \mathrm{m}^{2}$ ) between the island and the mainland; however, mainland beaches generally had higher percentages of miscellaneous plastic. The density of debris mass $\left(\mathrm{kg} / \mathrm{m}^{2}\right)$ was significantly different between islands and the mainland $\left(t_{11}=1.80, P=0.049\right)$, with the average debris mass density per beach being significantly greater on island beaches than on mainland beaches.

\section{Variation in Mainland Debris Accumulation, Fall 2015 and Winter 2016}

We tested for a seasonal effect on debris accumulation between Southern California's 


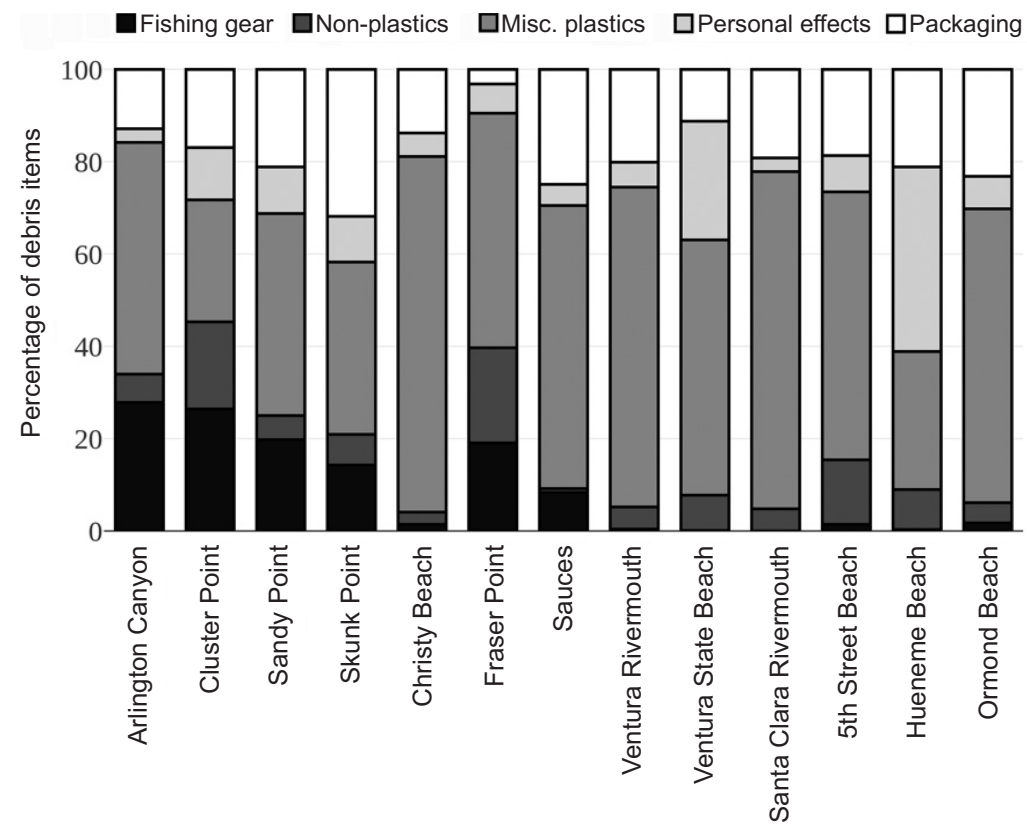

Fig. 2. Composition of marine debris differed between beaches of Santa Rosa Island (Arlington Canyon, Cluster Point, Sandy Point, Skunk Point) and Santa Cruz Island (Christy Beach, Fraser Point, Sauces) and the beaches of the mainland (Ventura Rivermouth through Ormond Beach). Fishing gear composed a significantly greater percentage of debris items found on the island beaches than on the mainland $\left(t_{11}=3.03, P<0.01\right)$. We observed no significant differences between the island and the mainland for other categories of debris items; however, mainland beaches generally had higher percentages of miscellaneous plastic.

drier fall season and the winter, usually characterized by episodic high wave and rainfall events. There was no difference between fall 2015 and winter 2016 in number of debris items across all mainland beaches $\left(t_{5}=0.65\right.$, $P=0.27$ ). There was no significant difference in debris mass collected from each beach in fall 2015 compared to winter $2016\left(t_{5}=0.76\right.$, $P=0.24)$; however, the total mass of winter 2016 debris $(31.81 \mathrm{~kg})$ across all mainland beaches was double that of debris collected in fall $2015(15.29 \mathrm{~kg})$.

\section{Relationship Between Microplastic Debris in Sediment and Density of Macroplastic Items}

The number of microplastic items per $100 \mathrm{~mL}$ of sand did not differ significantly between the islands and mainland $\left(F_{2,10}=2.03\right.$, $P=0.18)$. We assessed whether the density of microplastic items (items per $100 \mathrm{~mL}$ sand) was related to the presence of macroplastic items larger than $25 \mathrm{~mm}$ (items $/ \mathrm{m}^{2}$ ) (i.e., those items that would be collected by visual survey of beaches) using a linear regression. We found no significant relationship between the density of microplastics and macroplastics found per beach $\left(\mathrm{R}^{2}=0.03, P=0.62\right)$.

\section{Effect of Season on Historical Santa Rosa Island Marine Debris Density}

Four beaches on Santa Rosa Island (Arlington Canyon, Cluster Point, Sandy Point, and Skunk Point) were surveyed quarterly in each year from 1989 to 1993. Density of debris (items $/ \mathrm{m}^{2}$ ) did not differ significantly among years $\left(F_{4,43}=0.82, P=0.52\right)$; however, there was a significant difference in debris density among beaches $\left(F_{3,43}=36.24\right.$, $P<0.001)$ and among seasons $\left(F_{3,43}=3.72\right.$, $P=0.02)$. Density of debris items was higher in winter and spring, when rain and storm activity is more frequent, than in the drier, calmer summer and fall seasons. Time constraints and the difficulty of accessing the remote beaches prevented an examination of the effect of season on these 4 Santa Rosa Island Beaches in 2015-2016.

As there was no significant difference among years, the average density of debris 


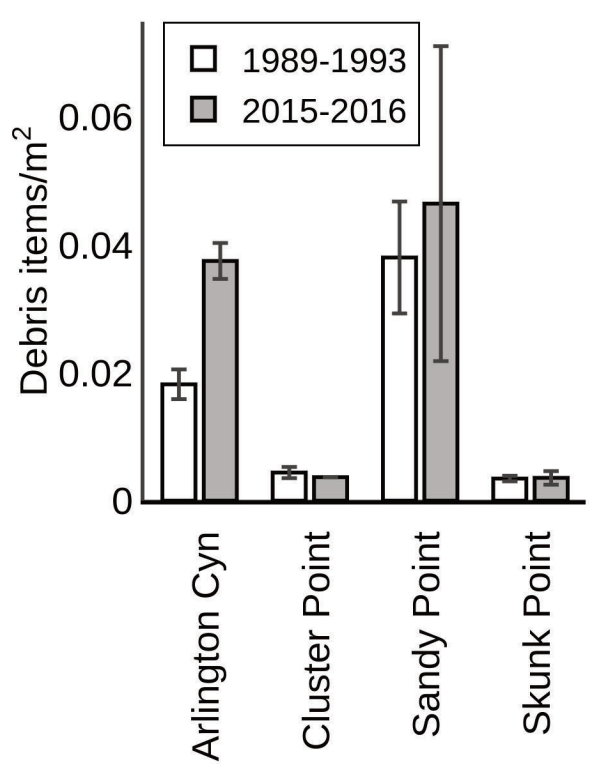

Fig. 3. Average debris item density across years for each of the 4 Santa Rosa Island beaches compared between the historical (1989-1993) and present (2015-2016) periods. The pattern of lower debris density at Cluster Point and Skunk Point as compared to Arlington Canyon and Sandy Point appeared consistent between time periods.

items $\left(\right.$ items $/ \mathrm{m}^{2}$ ) per beach was calculated for each year, and then the average item density across years for each of the 4 SRI beaches was compared between the historical (1989-1993) and present (2015-2016) periods using a paired $t$ test. There was no significant difference in the item density $\left(t_{3}\right.$ $=-1.02, P=0.19)$ between the 2 time periods; however, the pattern of lower debris density at Cluster Point and Skunk Point compared to Arlington Canyon and Sandy Point appeared consistent between the historical and current time periods (Fig. 3).

Historical Changes in Santa Rosa Island

Marine Debris Composition and Density

The composition of marine debris found on Santa Rosa Island in 2015 and 2016 has changed from that observed in the 19891994 surveys (Fig. 4). Comparing the proportions of debris in each category from the historic surveys to the present surveys shows that the proportion of derelict fishing gear found on the island has significantly increased across all SRI beaches $\left(t_{3}=3.37, P=0.04\right)$. Other debris categories did not have consistent patterns across all surveyed beaches. For example, the percentage of miscellaneous plastics found on SRI has decreased on Arlington Canyon, Cluster Point, and Sandy Point but has increased on Skunk Point.

\section{Discussion}

\section{Island and Mainland Debris Composition}

Anthropogenic marine debris accumulates on coastlines around the world, on even remote and uninhabited islands (Lavers and Bond 2017). The Southern California coastline and Channel Islands provide a useful contrast between the densely occupied mainland and the relatively remote and uninhabited islands. The relative seclusion of the Channel Islands and their protected area status does not prevent the accumulation of ocean-borne litter on their coastlines. Observed differences in marine debris composition suggest that mainland debris and island debris reflect different debris sources. Mainland debris is characterized by an abundance of miscellaneous plastics, likely from land-based sources via improper disposal, accidental loss, storm events, or sewage and drainage systems (Rech et al. 2014). Beaches on the Channel Islands had a relatively smaller proportion of landbased anthropogenic debris and a larger proportion of ocean-based debris. The majority of ocean-based debris is derelict fishing gear (McElwee et al. 2012), and the marine debris found on the islands reflected local fishing activities, particularly lobster fishing. The majority of land-based debris accumulating on the infrequently visited beaches of the islands is not directly deposited, but instead is likely carried there from inhabited coastlines elsewhere. Identifying the sources of marine debris on the Channel Islands can assist in identifying appropriate mitigation measures to reduce the accumulation of marine debris on the islands.

There was no relationship between the density of microplastics present and the density of macroplastic items $(>2.5 \mathrm{~cm})$. Therefore, the presence of microplastics is not predictive of the amount of macroplastic debris present at a beach. Patterns and processes of debris accumulation likely differ based on the size and type of debris. This is relevant because macroplastic debris items eventually break down into microplastics and therefore may contribute to microplastic density. 


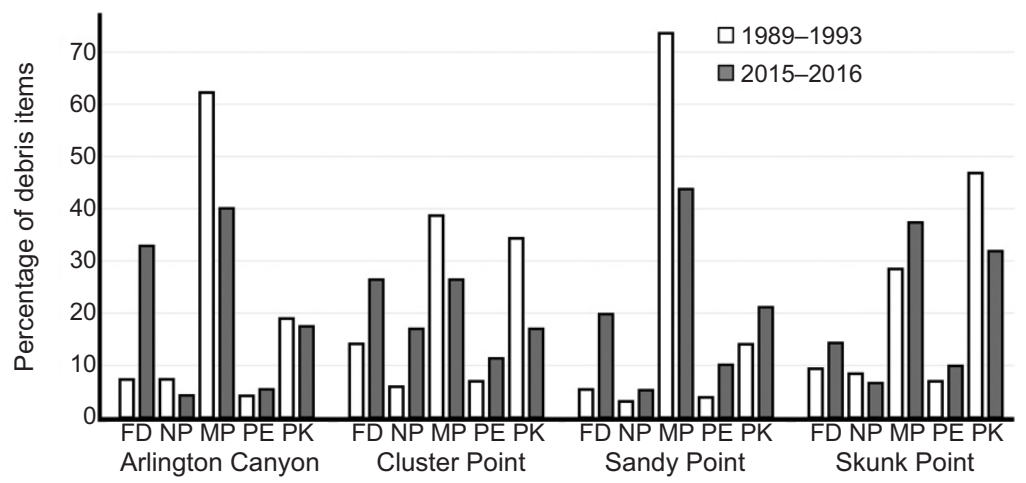

Fig. 4. Changes in marine debris composition between historical (1989-1993) and current (2015-2016) surveys of 4 beaches on Santa Rosa Island, California. Fishing debris (FD) increased significantly at all sites $\left(t_{3}=3.37, P=0.04\right)$. There was no consistent pattern of change across all beaches within the other marine debris categories $(\mathrm{NP}=$ nonplastics, $\mathrm{MP}=$ miscellaneous plastics, $\mathrm{PE}=$ personal effects, $\mathrm{PK}=$ packaging).

The Southern California climate is characterized by long periods of very low rainfall throughout summer and fall and episodic storms with higher rainfall and wave events in winter and spring. Rain and wave events might be expected to transport and redistribute landand ocean-based debris and affect accumulation of debris on shorelines. Examination of the quarterly surveys in the historical data for SRI revealed a significant effect of season on debris density, with higher density in the winters and springs. Comparison of beaches on the mainland before (fall 2015) and after (winter 2016) storm occurrences found double the total mass of debris in the winter; however, the pattern was not consistent among beaches. Beaches at or in close proximity to a rivermouth (Ventura Rivermouth, Santa Clara Rivermouth, and 5th Street Beach) had much higher debris counts in the winter surveys after January storm events than in the fall surveys. Rivers transport large amounts of anthropogenic litter from land-based sources to the oceans and beaches (Rech et al. 2014), which may be why the surveyed beaches at or in close proximity to a river mouth had more debris after winter storms. Further studies examining the relationship between debris transport via rivers and deposition on beaches would be beneficial to identifying more concrete seasonal trends in mainland marine debris accumulation specific to Ventura County.

\section{Historical Changes in Santa Rosa Island Marine Debris}

The proportion of marine debris that is derelict fishing gear on SRI has increased from 1989 to 1994 across all surveyed beaches. The Santa Barbara Channel and the Channel Islands are important habitat for commercial and recreational fisheries, such as the kelp bass and California sheephead (Caselle et al. 2015), red sea urchin (Kato and Schroeter 1985), and California spiny lobster (Kay et al. 2012) fisheries. Of all of these successful Santa Barbara Channel fisheries, the California spiny lobster commercial fishery is the most gear intensive. Commercial lobster fishermen deploy wire box-like traps from boats to catch California spiny lobster. Traps are usually deployed in $<31 \mathrm{~m}$ of water, but some are set as deep as $93 \mathrm{~m}$ (California Department of Fish and Wildlife 2016). Fishermen generally operate 75 to 1000 traps each season, with a median of 300 traps per fisherman (California Department of Fish and Wildlife 2016). While properly placed and serviced traps generally do not cause significant harm or disturbance to the marine environment (Eno et al. 2001), lost fishing traps no longer in use by fishermen can continue to fish for variable amounts of time, an ecologically harmful phenomenon known as ghost fishing (Brown and Macfadyen 2007). Lobster fishing efforts contribute regularly to marine debris and ghost fishing, because often the traps, lines, and buoys used in commercial lobster fishing are accidentally lost or discarded (Brown and Macfadyen 2007). Derelict fishing gear in marine environments is also known to entangle a number of marine mammal species (Avila-Forcada et al. 2012), and a portion of those entanglements may be attributable to the lobster fishery. 
Since the year 2000, there have been reported incidents of 4 gray whales (Eschrichtius robustus), 2 humpback whales (Megaptera novaeangliae), and 1 unidentified whale entangled in lobster gear from the California spiny lobster fishery (Carretta et al. 2015).

In California, commercial fishing effort has been increasing in recent years despite an overall decrease in the number of active fishermen since the late 1990s (California Department of Fish and Wildlife 2016). The increased effort could be driven by a number of factors. The annual number of commercial lobster trap pulls has increased to just over 1.1 million pulls in 2012 from around 800,000 pulls between 1995 and 2009 (California Department of Fish and Wildlife 2016). The number of active lobster fishermen in the state of California has remained relatively stable at about 150 permit-holding individuals since 2003 (California Department of Fish and Wildlife 2016). A commercial permit transferability was adopted in 2005 and has led to an increase in commercial trap pulls but a stable number of commercial fishermen (California Department of Fish and Wildlife 2016). The recent changes in the California spiny lobster fishery over the past 3 decades mirror the pattern of increasing fishing gear debris found on Santa Rosa Island. Overall, a higher number of trap pulls and an increase in commercial lobster fishing in California suggest more intensive lobster fishing pressure and deployment of more traps in the process. Lost fishing gear represents an unfortunate proportion (10\%) of marine debris worldwide (Macfadyen et al. 2009). A higher presence of derelict fishing gear puts the endangered birds and hauled-out pinnipeds inhabiting Santa Rosa Island's sandy beaches (Dugan et al. 2000) at higher risk of entanglement and other debris-associated hazards (Moore et al. 2009). In order to combat lost fishing gear stemming from the California spiny lobster fishery, new regulations for the 2017-2018 lobster fishing season have been implemented (California Department of Fish and Wildlife 2016). Commercial permit-holding lobster fisherman are now allowed only 300 traps per season, and at the end of the season lobster operator permit holders are required to report their trap loss.

Ongoing monitoring and surveys of Channel Island beaches are needed to monitor ongoing trends in lost fishing gear accumulation and to examine more specifically whether regulations in the commercial fishing industry are working to lessen the amount of derelict fishing gear. Ideally, future surveys would assess debris by mass as well as by item count. The historical debris surveys used for comparison in this study recorded item count only, which limits our ability to accurately assess changes through time. This is particularly important with regards to fishing debris such as lobster traps, which are relatively large, heavy, and therefore likely to be problematic for birds and marine mammals using beaches where debris has stranded. To further identify the effects of lobster fishing on Channel Island marine debris accumulation, it would be beneficial to survey island beaches before, after, and during lobster season, which runs annually from October to March (California Department of Fish and Wildlife 2016).

\section{Importance of Monitoring Marine Debris}

Monitoring marine debris can clarify the sources, types, and depth of marine debris pollution and can also provide a framework to create management decisions (Ribic et al. 2010). There is a lack of data in the published literature on the ecological and economic impacts of derelict fishing gear in coastal ecosystems (Arthur et al. 2014). This lack of data needs to be addressed with the consistent monitoring of marine debris. Monitoring marine debris can also demonstrate the effect of changes in policy and consumer culture. The remote and protected beaches of the Channel Islands provide useful information on rates of accumulation of ocean-borne marine debris because of infrequent visitation and relatively little direct deposition onto the shoreline. Monitoring the Channel Islands can assist with examining changes in the composition and quantity of marine debris resulting from regional changes in policy (e.g., the SB-270 California ban on single-use plastic bags) and on international policy changes (e.g., the MarPol Annex V, which regulates pollution from garbage generated on commercial ships) (Chen and Liu 2013). Monitoring the accumulation rates of discarded and lost fishing gear can make it possible to assess whether changes in local fisheries regulations correlate to changes in marine debris types and accumulation. 
There are important differences in mainland and island marine debris composition, with mainland debris being dominated by land-based sources and island debris having a higher proportion of ocean-based sources, like derelict fishing gear. The marine debris composition on Santa Rosa Island has changed since the early 1990s, and derelict fishing gear now composes a much larger portion of the marine debris. Efforts of the commercial California spiny lobster fishery have also increased since the early 1990s (California Department of Fish and Wildlife 2016), possibly explaining the increase in fishing gear on Santa Rosa Island.

The Northern Channel Islands, comprising a National Park and a National Marine Sanctuary, encompass important protected coastal and marine habitat in Southern California, and this study highlights the importance of facilitating an adequate and substantial management program to combat the accumulation of marine debris on the Channel Islands. This study also stresses the need for a long-term marine debris monitoring program to be implemented on the Channel Islands, as there is a constant need to conserve and protect the California coastline and monitor the effects of local commercial and recreational fisheries, dense urban populations, and changes in policy and consumer culture on coastal and marine environments.

\section{Literature Cited}

Anderson, J.A., And A.B. Alford. 2014. Ghost fishing activity in derelict blue crab traps in Louisiana. Marine Pollution Bulletin 79:261-267.

ANDRADY, A.L. 2011. Microplastics in the marine environment. Marine Pollution Bulletin 62:1596-1605.

Arthur, C., A.E. Sutton-Grier, P. Murphy, and H. BAMFORD. 2014. Out of sight but not out of mind: harmful effects of derelict traps in selected U.S. coastal waters. Marine Pollution Bulletin 86:19-28.

Avila-Forcada, S., A.L. Martínez-CruZ, and C. MuñozPIÑA. 2012. Conservation of vaquita marina in the Northern Gulf of California. Marine Policy 36: 613-622

Barnes, D.K.A., F. Galgani, R.C. Thompson, and M. BARLAZ. 2009. Accumulation and fragmentation of plastic debris in global environments. Philosophical Transactions: Biological Sciences 364:1985-1998.

Bartholomew, G.A., and R.A. Boolootian. 1960. Numbers and population structure of the pinnipeds on the California Channel Islands. Journal of Mammalogy 41:366-375.

Brander, S.M., R.E. Fontana, T.M. Mata, S.A. Gravem, A. Hettinger, J.R. Bean, A.I. Szoboszlai, C.A. KeIPER, AND M.E. MarRero. 2011. The ecotoxicology of plastic marine debris. American Biology Teacher 73:474-478.

Bravo, M., M. de los Ángeles Gallardo, G. LunaJorquera, P. Núñez, N. VÁsquez, and M. Thiel. 2009. Anthropogenic debris on beaches in the SE Pacific (Chile): results from a national survey supported by volunteers. Marine Pollution Bulletin 58:1718-1726.

Brown, J., and G. Macfadyen. 2007. Ghost fishing in European waters: impacts and management responses. Marine Policy 31:488-504.

Browne, M.A., P. Crump, S.J. Niven, E. Teuten, A. Tonkin, T. Galloway, and R. Thompson. 2011. Accumulation of microplastic on shorelines worldwide: sources and sinks. Environmental Science and Technology 45:9175-9179.

California Department of Fish and Wildlife. 2016. California spiny lobster fishery management plan. California Department of Fish and Wildlife.

Carretta, J.V., E.M. Oleson, D.W. Weller, A.R. Lang, K.A. Forney, J. Baker, M.M. Muto, B. Hanson, A.J. OrR, H. Huber, ET AL. 2015. U.S. Pacific Marine Mammal Stock Assessments: 2014. National Oceanic and Atmospheric Administration.

Caselle, J.E., A. Rassweiler, S.L. Hamilton, and R.R. WARNER. 2015. Recovery trajectories of kelp forest animals are rapid yet spatially variable across a network of temperate marine protected areas. Scientific Reports 5:14102.

Chen, C., AND D. Lopez-Carr. 2015. The importance of place: unraveling the vulnerability of fisherman livelihoods to the impact of marine protected areas. Applied Geography 59:88-97.

Chen, C.-L., AND T.-K. Liu. 2013. Fill the gap: developing management strategies to control garbage pollution from fishing vessels. Marine Policy 40:34-40.

Claessens, M., L. Van Cauwenberghe, M.B. VandegeHuChTE, AND C.R. JANSSEN. 2013. New techniques for the detection of microplastics in sediments and field collected organisms. Marine Pollution Bulletin $70: 227-233$

Cole, C.A. 1998. Final report of the National Park Marine Debris Monitoring Program. National Park Service.

Coonan, T.J., C.A. Schwemm, G.W. Roemer, D.K. Garcelon, L. Munson, and C.A. Jones. 2005. Decline of an island fox subspecies to near extinction. Southwestern Naturalist 50:32-41.

Crossett, K.M., T.J. Culliton, P.C. Wiley, and T.R. GoodspeEd. 2004. Population trends along the coastal United States: 1980-2008. National Oceanic and Atmospheric Administration.

Derraik, J.G.B. 2002. The pollution of the marine environment by plastic debris: a review. Marine Pollution Bulletin 44:842-852.

Díaz-Uribe, J.G., F. Arreguín-Sánchez, D. LercariBernier, V.H. Cruz-Escalona, M.J. Zetina-Rejón, P. DEL-Monte-Luna, and S. Martínez-Aguilar. 2012. An integrated ecosystem trophic model for the North and Central Gulf of California: an alternative view for endemic species conservation. Ecological Modelling 230:73-91.

Dugan, J.E., D.M. Hubbard, D.L. Martin, J.M. Engle, D.M. Richards, G.E. Davis, K.D. Lafferty, and R.F. Ambrose. 2000. Macrofauna communities of exposed sandy beaches on the Southern California mainland and Channel Islands. Proceedings of the 
Fifth California Islands Symposium. Minerals Management Service Publication 99-0038.

Dugan, J.E., D.M. Hubbard, And A.M. Wenner. 1998. A catalog of the sandy beaches of San Luis Obispo and Santa Barbara Counties. Report to Minerals Management Service, Camarillo, CA.

ENGLER, R.E. 2012. The complex interaction between marine debris and toxic chemicals in the ocean. Environmental Science and Technology 46:12302-12315.

Eno, N.C., D.S. MacDonald, J.A.M. Kinnear, S.C. Amos, C.J. Chapman, R.A. Clark, F.S.P.D. Bunker, AND C. MunRo. 2001. Effects of crustacean traps on benthic fauna. ICES Journal of Marine Science: Journal du Conseil 58:11-20.

Fendall, L.S., And M.A. Sewell. 2009. Contributing to marine pollution by washing your face: microplastics in facial cleansers. Marine Pollution Bulletin 58: $1225-1228$.

Gilman, E. 2015. Status of international monitoring and management of abandoned, lost and discarded fishing gear and ghost fishing. Marine Policy 60: 225-239.

Gouin, T., N. Roche, R. Lohmann, and G. Hodges. 2011. A thermodynamic approach for assessing the environmental exposure of chemicals absorbed to microplastic. Environmental Science and Technology 45:1466-1472.

Gregory, M.R. 1996. Plastic 'scrubbers' in hand cleansers: a further (and minor) source for marine pollution identified. Marine Pollution Bulletin 32: 867-871.

Havens, K., D.M. Bilkovic, D. Stanhope, and K. AnGSTADT. 2011. Fishery failure, unemployed commercial fishers, and lost blue crab pots: an unexpected success story. Environmental Science and Policy 14:445-450.

IVAR DO SUL, J.A., AND M.F. Costa. 2014. The present and future of microplastic pollution in the marine environment. Environmental Pollution 185:352-364.

Johnson A., G. Salvador, J. Kenney, J. Robbins, S. Kraus, S. Landry, and P. Clapham. 2006. Fishing gear involved in entanglements of right and humpback whales. Marine Mammal Science 21:635-645

Kato, S., And S.C. Schroeter. 1985. Biology of the red sea urchin, Strongylocentrotus franciscanus, and its fishery in California. Marine Fisheries Review 47: $1-20$.

KaY, M.C., H.S. Lenihan, C.M. Guenther, J.R. Wilson, C.J. Miller, and S.W. Shrout. 2012. Collaborative assessment of California spiny lobster population and fishery responses to a marine reserve network. Ecological Applications 22:322-335.

Lavers, J.L., AND A.L. Bond. 2017. Exceptional and rapid accumulation of anthropogenic debris on one of the world's most remote and pristine islands. Proceedings of the National Academy of Sciences 114:6052-6055.

Lippiatt, S., S. Opfer, and C. Arthur. 2013. Marine debris monitoring and assessment: recommendations for monitoring debris trends in the marine environment. NOAA Technical Memorandum NOSOR\&R-46. $82 \mathrm{pp}$.

Macfadyen, G., T. Huntington, and R. Cappell. 2009 Abandoned, lost or otherwise discarded fishing gear. UNEP Regional Seas Reports and Studies No. 185; FAO Fisheries and Aquaculture Technical Paper No. 523. Rome, UNEP/FAO. 115 pp.
McElwee, K., M.J. Donohue, C.A. Courtney, C. MorISHIGE, AND A. RIVERA-VICENTE. 2012. A strategy for detecting derelict fishing gear at sea. Marine Pollution Bulletin 65:7-15.

Moore, C.J. 2008. Synthetic polymers in the marine environment: a rapidly increasing, long-term threat. Environmental Research 108:131-139.

Moore, C.J., G.I. LatTin, AND A.F. Zellers. 2011. Quantity and type of plastic debris flowing from two urban rivers to coastal waters and beaches of Southern California. Journal of Integrated Coastal Zone Management 11:65-73.

Moore, E., S. Lyday, J. Roletto, K. Litle, J.K. Parrish, H. Nevins, J. Harvey, J. Mortenson, D. Greig, M. PIAZZA, ET AL. 2009. Entanglements of marine mammals and seabirds in central California and the north-west coast of the United States 2001-2005. Marine Pollution Bulletin 58:1045-1051.

Moore, S.L., And M.J. Allen. 2000. Distribution of anthropogenic and natural debris on the mainland shelf of the Southern California Bight. Marine Pollution Bulletin 40:83-88.

Morishige, C., AND K. MCElwee. 2012. At-sea detection of derelict fishing gear in the North Pacific: an overview. Marine Pollution Bulletin 65:1-6.

Noble, M.A., K.J. Rosenberger, L.K. Rosenfeld, and G.L. Robertson. 2012. Temporal and spatial patterns in wind stress and wind stress curl over the central Southern California Bight. Continental Shelf Research 38:98-109.

Patsch, K., AND G. GRiggs. 2008. A sand budget for the Santa Barbara Littoral Cell, California. Marine Geology 252:50-61.

Rech, S., V. Macaya-Caquilpán, J.F. Pantoja, M.M. Rivadeneira, D. Jofre Madariaga, and M. Thiel. 2014. Rivers as a source of marine litter-a study from the SE Pacific. Marine Pollution Bulletin $82(1-2): 66-75$.

Ribic, C.A., S.B. Sheavly, D.J. Rugg, and E.S. Erdmann. 2010. Trends and drivers of marine debris on the Atlantic Coast of the United States 1997-2007. Marine Pollution Bulletin 60:1231-1242.

Ribic, C.A., S.B. Sheavly, D.J. RugG, and E.S. Erdmann. 2012. Trends in marine debris along the U.S. Pacific Coast and Hawai'i 1998-2007. Marine Pollution Bulletin 64:994-1004

Schroeder, D.M., AND M.S. Love. 2002. Recreational fishing and marine populations in California. California Cooperative Oceanic Fisheries Investigations Report:182-190.

Taylor, A.G., M.R. Landry, K.E. Selph, and J.J. WokULUK. 2015. Temporal and spatial patterns of microbial community biomass and composition in the Southern California Current Ecosystem. Deep Sea Research Part II: Topical Studies in Oceanography 112:117-128.

Thompson, R.C., Y. Olsen, R.P. Mitchell, A. Davis, S.J. Rowland, A.W. John, D. McGonigle, and A.E. RusselL. 2004. Lost at sea: where is all the plastic? Science 304:838.

United States Census Bureau. 2018. QuickFacts: Santa Barbara County, California. [Accessed 4 April 2018]. https://www.census.gov/quickfacts/fact/map/santa barbaracountycalifornia/INC110216

Warrick, J.A., L.A.K. Mertes, L. Washburn, and D.A. SIEGEL. 2004a. A conceptual model for river water and sediment dispersal in the Santa Barbara 
Channel, California. Continental Shelf Research 24:2029-2043

Warrick, J.A., L.A.K. Mertes, L. Washburn, and D.A. SIEGEL. 2004b. Dispersal forcing of southern California river plumes, based on field and remote sensing observations. Geo-Marine Letters 24:46-52.

WatTers, D.L., M.M. YoKLavich, M.S. Love, and D.M. Schroeder. 2010. Assessing marine debris in deep seafloor habitats off California. Marine Pollution Bulletin 60:131-138.
Willis, C.M., AND G. GRIgGs. 2003. Reductions in fluvial sediment discharge by coastal dams in California and implications for beach sustainability. Journal of Geology 111:167-182.

Received 6 March 2017

Revised 10 April 2018

Accepted 2 May 2018

Published online 13 September 2018 